\title{
POLA SEBARAN KEKERINGAN DI KECAMATAN SIMPENAN MENGGUNAKAN METODE SPI
}

\section{(STANDARDIZED PRECIPITATION INDEX)}

\author{
Ratri Widyastuti ${ }^{1}$, Mangapul Parlindungan Tambunan ${ }^{2}$, Taqyuddin ${ }^{2}$, Rudy Parluhutan Tambunan ${ }^{2}$ \\ ${ }^{1}$ Magister IImu Geografi, Fakultas Matematika dan Ilmu Pengetahuan Alam, Universitas Indonesia \\ ${ }^{2}$ Departemen Geografi, Fakultas Matematika dan IImu Pengetahuan Alam, Universitas Indonesia \\ e-mail : ratriwidyastuti28@gmail.com
}

\begin{abstract}
Abstrak. Monitoring kekeringan menjadi salah satu kegiatan penting yang dapat dilakukan dengan berbagai macam metode. Penelitian ini menggunakan data curah hujan hasil observasi dari stasiun pengamatan curah hujan milik BMKG yang berada di Kecamatan Simpenan, Jawa Barat, dan data produksi hasil pertanian yaitu padi sawah dan bawang merah yang merupakan salah satu komoditas unggulan di Kecamatan Simpenan, Jawa Barat. Penelitian ini bertujuan untuk mengetahui pola sebaran kekeringan di Kecamatan Simpenan berdasarkan analisis SPI (Standardized Precipitation Index) yang di kategorikan dalam 7 kelompok yaitu sangat basah, basah, agak basah, normal, kering, agak kering, sangat kering, dan juga mengetahui pengaruh kekeringan terhadap hasil produktivitas pertanian unggulan di Kecamatan Simpenan yaitu padi sawah dan bawang merah. Nilai SPI kemudian dipetakan dengan ArcGIS menggunakan metode Inverse Distance Weighted (IDW) untuk melihat pola sebaran kekeringan secara spasial. Dari hasil pengolahan didapatkan nilai SPI tertinggi terjadi pada bulan Januari hingga Februari dengan rentang nilai 1,00 s.d 1,71, yang termasuk dalam kategori agak basah hingga basah. Nilai SPI terendah terjadi pada bulan September hingga Oktober dengan rentang nilai $-1,50$ s.d $-1,99$. Kondisi kekeringan yang terjadi di Kecamatan Simpenan berpengaruh terhadap hasil produksi pertanian varietas unggulan yaitu padi sawah dan bawang merah. Produktivitas tertinggi untuk padi sawah dan bawang merah terjadi pada bulan Maret dengan hasil panen padi sawah 296 ton/ha, dan bawang merah 70 kwintal/ha. Penurunan produktivitas padi sawah dan bawang merah terjadi pada bulan Agustus dengan hasil panen padi sawah 50 ton/ha, dan bawang merah $43 \mathrm{kwintal} / \mathrm{ha}$.
\end{abstract}

Kata Kunci: Kekeringan; Indeks Presipitasi Standar; Kecamatan Simpenan

\begin{abstract}
Drought Monitoring is one of the most important activities that can be done in a variety of methods. This research uses the observation of rainfall data from BMKG's rainfall observation station in Simpenan sub-district, West Java, and agricultural production data of rice paddy fields and shallots which is one of the flagship commodity in Simpenan sub-district, West Java. This research aims to know the pattern of drought distribution in Simpenan district based on the analysis of SPI (Standardized Precipitation Index) which is categorized in 7 groups that are very wet, wet, slightly wet, normal, dry, somewhat dry, very dry, and also know the influence of drought on the results of the superior agricultural productivity in Simpenan subdistrict namely rice fields and shallots. The value of SPI is then mapped with ArcGIS using the Inverse Distance Weighted (IDW) method for spatial viewing of drought-spread patterns. From the processing results obtained the highest SPI value occurred in January to February with a range of value $1.00 \mathrm{~S}$. D 1.71, which belongs to the category is slightly wet to wet. The lowest SPI value occurs between September and October with a value range of-1.50 s. D-1.99. The drought condition that occurs in the subdistrict of Simpenan affects the production of the agricultural products of superior varieties of rice paddy and shallots. The highest productivity for paddy fields and shallots occurred in March with the harvest of 296 tons/ha rice paddy, and shallot $70 \mathrm{kwintal} / \mathrm{ha}$. The decrease in productivity of rice paddy fields and shallots occurred in August with the harvest of 50 tons/ha rice paddy, and shallot $43 \mathrm{kwintal} / \mathrm{ha}$. Keywords: Drought; Standard Precipitation Index; Simpenan Subdistrict
\end{abstract}

\section{PENDAHULUAN}

Kekeringan merupakan ancaman yang sering kali terjadi di beberapa wilayah Indonesia setiap tahunnya. Salah satu dampak yang terjadi akibat kekeringan yaitu mengeringnya daerah aliran sungai dan juga sumur air yang menjadi sumber kehidupan bagi manusia. Umumnya kekeringan berlangsung dalam kurun waktu yang cukup lama ( 3-6 bulan) hingga musim penghujan tiba. Ancaman kekeringan ditandai dengan berkurangnya curah hujan, suhu 
udara yang mencapai diatas normal $\left(>35^{\circ} \mathrm{C}\right)$, dan pasokan air tanah yang tidak mencukupi.

Menurut (Jeyaseelan, 2004), kekeringan dibagi menjadi kekeringan meterologis, kekeringan hidrologis, dan kekeringan pertanian. Kekeringan meteorologis berkaitan dengan tingkat curah hujan di bawah normal dlam satu musim yang menyebabkan berkurangnya runoff dan air tanah, temperatur udara yang tinggi, angin kencang, kelembaban udara rendah, dan meningkatnya evaporasi dan transpirasi. Kekeringan meteorologis yang terjadi kemudian mengakibatkan munculnya kekeringan pertanian. Kekeringan pertanian menyebabkan berkurangnya kandungan air dalam tanah untuk memenuhi kebutuhan tanaman sehingga dapat menyebabkan terjadinya gagal panen (puso). Kekeringan pertanian ini terjadi juga disebabkan oleh kekeringan hidrologis yang identik dengan kurangnya pasokan air permukaan dan air tanah.

Selama periode musim kemarau, ancaman kekeringan sering kali terjadi hampir di seluruh wilayah Indonesia. Permasalahan kekeringan di Indonesia dirasakan di sebagian wilayah termasuk di Kabupaten Sukabumi, Jawa Barat. Berdasarkan data dari Badan Penanggulangan Bencana Daerah Kabupaten Sukabumi, sebanyak 12 kecamatan di Kabupaten Sukabumi mengalami dampak kekeringan diantaranya, Kecamatan Cisolok, Cikakak, Palabuhanratu, Simpenan, Bantargadung, Gunungguruh, Gegerbitung, Cibadak, Sukalarang, Cicurug, dan Cikembar. Kecamatan Simpenan merupakan salah satu yang kecamatan yang terdampak kekeringan paling besar (BPBD Kabupaten Sukabumi, 2019). Pada Kecamatan Simpenan terdiri dari 7 desa yaitu Loji, Cidadap, Cibuntu, Mekarasih, Sangrawayang, Kertajaya, Cihaur.

Penyebab kegagalan produksi tanaman pangan di Indonesia adalah kekeringan (Rahayu, S. P., 2011). Untuk mengatasinya diperlukan upaya dalam mengetahui dan memahami karakteristik iklim pada setiap daerah. Oleh karena itu diperlukan suatu indeks yang dapat menggambarkan tingkat kekeringan di suatu daerah. Indeks kekeringan yang umum digunakan yaitu Standard Precipitation Index (SPI). Mc Kee pada tahun 1993 pertama kali mengembangkan SPI sebagai salah satu metode untuk mengidentifikasi kekeringan dan mengevaluasi tingkat kekeringan (McKee dkk., 1993). SPI sering digunakan karena dapat memberikan perbandingan yang relatif mudah pada kondisi iklim dan tempat yang berbeda (Bordi dkk., 2009).

SPI merupakan sebuah metode yang dikembangkan untuk mendefinisikan dan memonitoring kekeringan dari data time scale (skala temporal atau resolusi temporal) berdasarkan data historis curah hujan di wilayah tertentu. Selain itu, SPI juga dapat digunakan untuk menentukan periode anomali dari kejadian basah. Indeks SPI dapat digunakan pada berbagai skala waktu 1, 3, 6, 12, dan maksimal 72 bulan, sehingga dapat melihat kondisi kekeringan yang terjadi dengan mudah di setiap daerah (World Meteorological Organization, 2017). Penelitian ini bertujuan untuk mengetahui pola sebaran kekeringan di Kecamatan Simpenan berdasarkan nilai SPI. Tujuan berikutnya adalah untuk mengetahui pengaruh kekeringan terhadap produksi pertanian di Kecamatan Simpenan.

\section{METODOLOGI}

Data yang digunakan dalam penelitian ini berupa data curah hujan yang bersumber dari hasil observasi pos penakar hujan milik Badan Meteorologi Klimatologi dan Geofisika (BMKG) di Kecamatan Simpenan, dan data produksi pertanian bawang merah dan padi sawah tahun 2019 yang bersumber dari Dinas Pertanian Kabupaten Sukabumi. Penelitian ini dilakukan pada bulan Oktober 2019, sehingga data yang tersedia dan juga data yang digunakan untuk tahun 2019 baru sampai pada bulan Oktober. Pada prinsipnya SPI menghitung peluang-peluang dari curah hujan untuk setiap skala waktu (bulanan). Mencocokkan fungsi kepadatan peluang Gamma terhadap sebaran frekuensi jumlah curah hujan bulanan untuk setiap wilayah. Tom, (1996) dalam (McKee dkk., 1993) 
menyatakan bahwa sebaran gamma cocok untuk beberapa data klimatologi seperti data curah hujan bulanan. Secara matematis SPI dihitung berdasarkan cumulative probability function dari kejadian hujan yang terjadi di stasiun tertentu. Data curah hujan historis di satu titik di cocokan dengan distribusi gamma. Distribusi gamma digunakan karena telah dibuktikan mendekati distribusi curah hujan dengan cukup bagus. Selanjutnya, penyelesaian dilakukan dengan perhitungan estimasi likelihood dari parameter distribusi gamma yaitu, parameter $\alpha$ dan $\beta$. Oleh karena itu, berdasarkan data historis, suatu peluang kejadian curah hujan dapat dikatakan kurang atau sama dengan suatu nilai tertentu.

$$
g(x)=\frac{1}{\beta^{\alpha} \Gamma} \int_{0}^{x} x^{a-1} e^{-x / \beta} d x
$$

dengan:

$\beta=$ parameter bentuk

$\alpha=$ parameter skala

$\Gamma=$ fungsi gamma

$\mathrm{x}=$ curah hujan

Langkah-langkah penghitungan SPI Banyak ditemukan dalam berbagai jurnal ilmiah seperti pada (Kumar dkk., 2009), (Khan dan Gadiwala, 2013), dan (Triatmoko dkk., 2012). Hasil perhitungan rata-rata curah hujan bulanan kemudian dikonversi kedalam nilai SPI.

Tabel 1. Klasifikasi Kekeringan Berdasarkan Nilai SPI

\begin{tabular}{lc}
\hline Klasifikasi kekeringan & Nilai SPI \\
\hline Sangat basah & $\geqslant 2,00$ \\
Basah & 1,50 sd 1,99 \\
Agak basah & 1,00 sd 1,49 \\
Normal & $-0,99$ sd 0,99 \\
Agak Kering & $-1,00$ sd $-1,49$ \\
Kering & $-1,50$ sd $-1,99$ \\
Sangat kering & $\leqslant-2,00$ \\
\hline
\end{tabular}

Sumber : T.B. Mc Kee., (1993)

Pembuatan peta administrasi Kecamatan Simpenan serta input data dengan menggunakan software ArcGIS 10.4 melalui metode Metode Inverse Distance Weighted (IDW) memiliki asumsi bahwa setiap titik input mempunyai pengaruh yang bersifat lokal dan berkurang terhadap jarak. Pada metode interpolasi IDW pada umumnya dipengaruhi oleh inverse jarak yang diperoleh dari persamaan matematika. Pengaruh akan lebih besar dari titik input dengan titik yang lebih dekat sehingga menghasilkan permukaan yang lebih detail. Namun seiring bertambahnya jarak pengaruh akan semakin berkurang detailnya dan terlihat lebih halus untuk mengetahui persebaran secara spasial dan identifikasi daerah yang mengalami kekeringan

Analisis data yang dilakukan dalam penelitian ini berupa analisis spasial pola sebaran kekeringan berdasarkan hasil pengolahan pemetaan indeks kekeringan guna mengetahui pola sebaran kekeringan yang terjadi di Kecamatan Simpenan sepanjang tahun 2019. Data produksi pertanian dilakukan menggunakan analisis deskriptif guna mengetahui jumlah produksi pertanian di Kecamatan Simpenan dan dihubungkan dengan kejadian kekeringan yang terjadi di Kecamatan Simpenan tahun 2019.

\section{HASIL DAN PEMBAHASAN}

\section{Analisis Sebaran Kekeringan Bulan Januari - April 2019.}

Pada bulan Januari hingga Februari secara umum kondisi di Kecamatan Simpenan berada pada kategori agak basah hingga basah (Gambar 1.a) dengan nilai SPI (1,00 s.d 1,71). Memasuki bulan Maret sebagian besar wilayah di Kecamatan Simpenan berada pada kategori agak basah (Gambar 1.b) dengan nilai SPI 1,00 s.d 1,23, kecuali di Desa Loji, Desa Cibuntu bagian Selatan, Desa Kertajaya bagian Barat Laut, Desa Cihaur bagian Timur Laut, Desa Sangrawayang bagian Timur, dan Desa Cidadap bagian Tenggara berada pada kategori normal dengan nilai SPI -0,99. Pada bulan April (Gambar 2.b) sebagian besar wilayah di Kecamatan Simpenan berada pada kategori normal dengan nilai SPI -0,34 s.d 0,71 kecuali di Desa Loji berada pada kategori Agak Kering dengan nilai SPI 1,09 . 


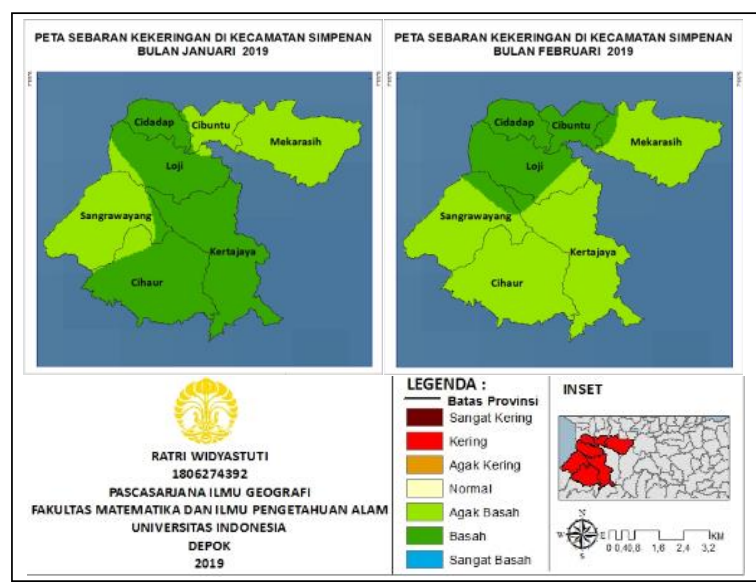

(a)

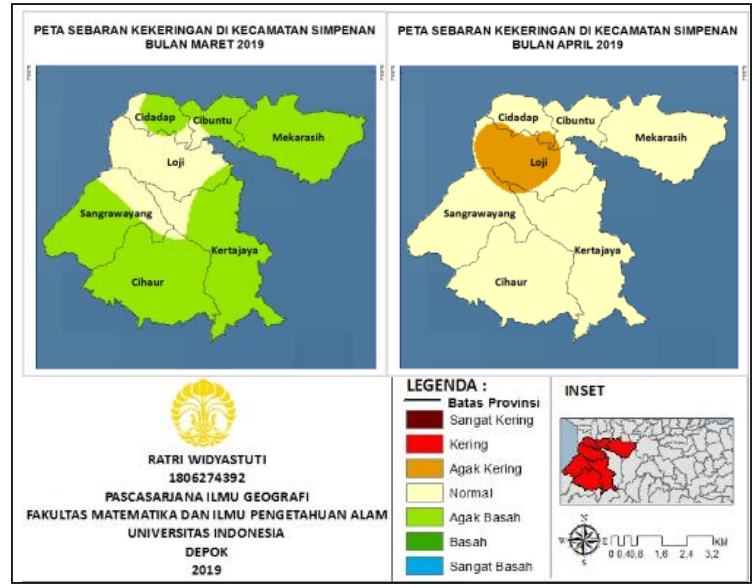

(b)

Gambar 1. Peta sebaran kekeringan di Kecamatan Simpenan Bulan Januari - Februari 2019 (a) dan MaretApril 2019 (b)

\section{Analisis Sebaran Kekeringan Bulan Mei - Agustus} 2019.

Pada bulan Mei hingga Agustus beberapa wilayah di Kecamatan Simpenan sudah mulai memasuki kategori agak kering hingga sangat kering (Gambar 2.a) dengan rentang nilai SPI -1,1,3 s.d 2.2. Kategori sangat kering terjadi pada bulan Mei di Desa Kertajaya bagian Timur dan sebagian kecil Desa Loji bagian Tenggara dengan nilai SPI -2.2. Untuk kategori normal dengan nilai SPI $(-0,71$ s.d $0,17)$ terjadi di sebagian Desa Mekarasih dan Desa Sangrawayangpada bulan Mei. Kategori agak kering dengan nilai SPI $-1,00$ s.d 1,31 terjadi pada bulan Juni hampir di sebagian besar Kecamatan Simpenan, kecuali di Desa Loji berada pada kategori kering dengan nilai SPI -1,69 dan Desa Mekarasih berada pada kategori normal dengan nilai SPI -0,81.

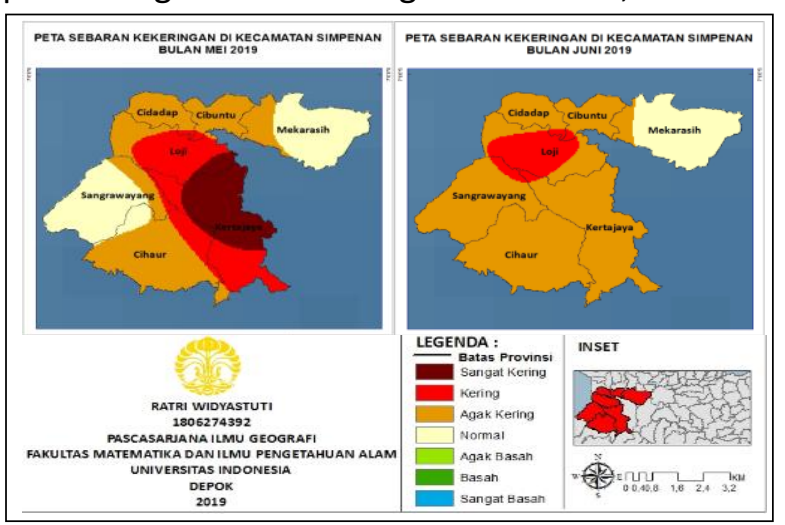

(a)

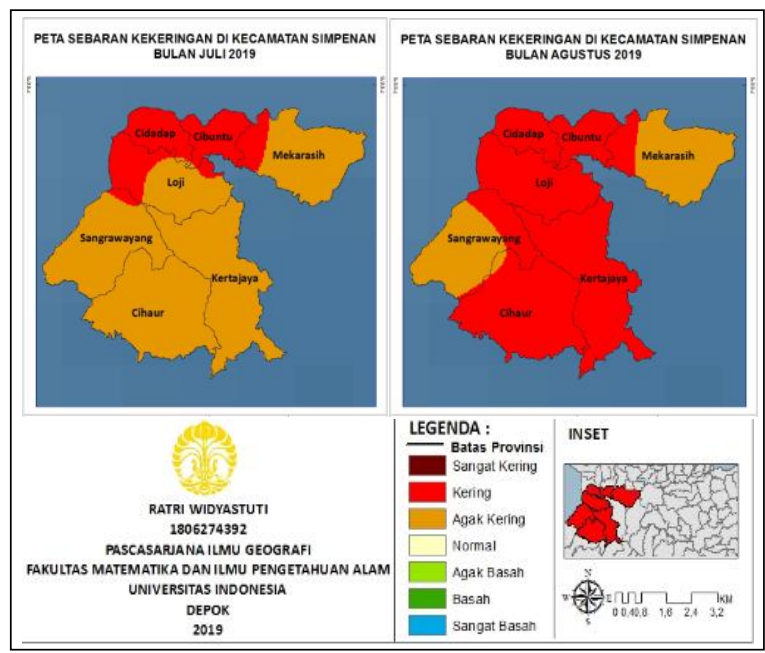

(b)

Gambar 2. Peta sebaran kekeringan di Kecamatan Simpenan Bulan Mei - Juni 2019 (a) dan Agustus September 2019 (b)

Memasuki bulan Juli hingga Agustus (Gambar 2.b) kondisi wilayah di Kecamatan Simpenan secara keseluruhan berada pada kategori kering dengan nilai SPI $-1,71$ s.d $-1,99$ yang merata terjadi di seluruh Desa Loji, Desa Cidadap, Desa Cibuntu, Desa Kertajaya,dan Desa Cihaur. Untuk kategori agak kering terjadi di Desa Mekarasih dan Desa Sangrawayang dengan nilai SPI -1,19 s.d -1,26.

\section{Analisis Sebaran Kekeringan Bulan September- Oktober 2019.}

Pada bulan September hingga Oktober (Gambar 4) kondisi wilayah di Kecamatan Simpenan secara keseluruhan berada pada kategori kering dengan nilai SPI -1,51 s.d -1,99. 


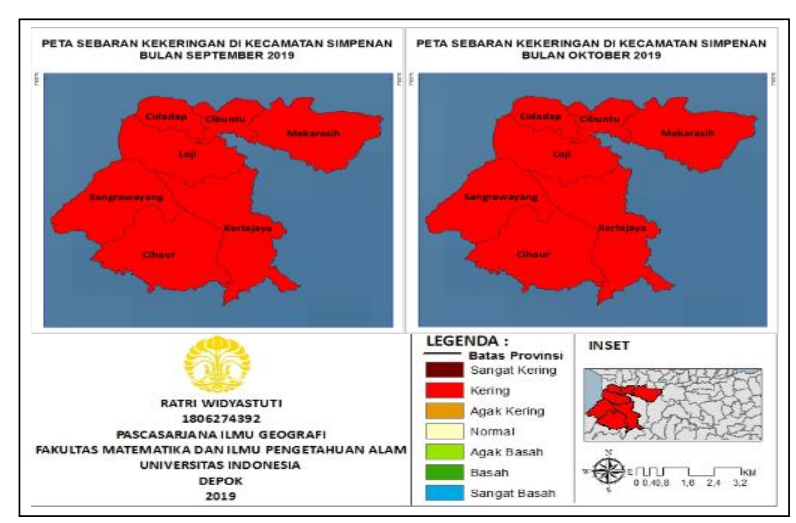

Gambar 4. Peta sebaran kekeringan di Kecamatan Simpenan Bulan September-Oktober 2019

\section{Analisis Produktivitas Pertanian di Kecamatan Simpenan Tahun 2019}

Kondisi iklim merupakan salah satu faktor eksogen yang mempengaruhi proses produksi hasil pertanian. Produksi pertanian yang dicapai oleh perani tidak selalu sesuai dengan yang di targetkan setiap bulannya akibat pengaruh cuaca dan iklim yang tidak menentu. Varietas pertanian yang menjadi unggulan di Kecamatan Simpenan yaitu bawang merah dan padi sawah. Pertumbuhan kedua varietas unggulan tersebut sangat ditentukan oleh cuaca dan iklim yang terjadi pada saat proses mulai dari penanaman bibit hingga proses panen.

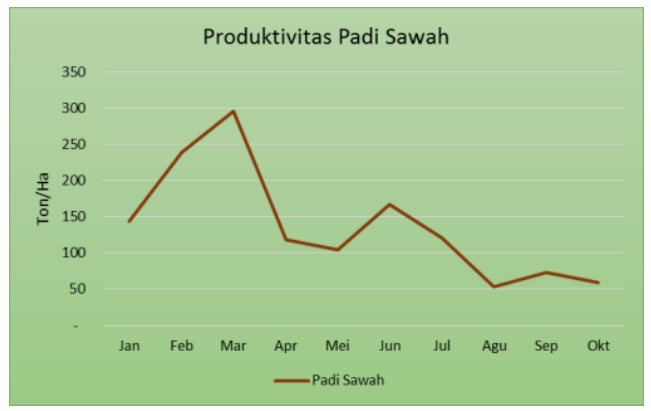

(a)

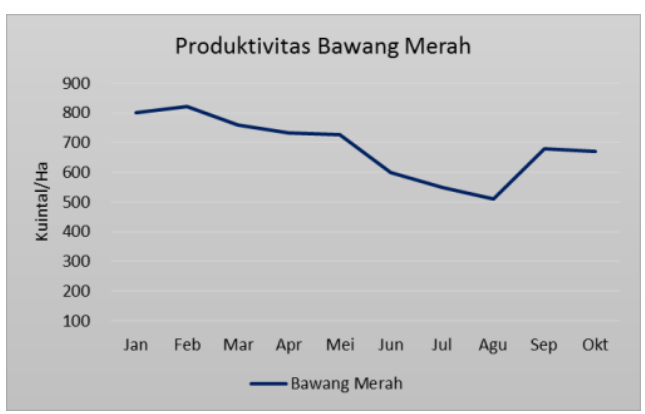

(b)
Gambar 4. Grafik produktivitas tanaman padi sawah (a) dan bawang merah (b) di Kecamatan Simpenan Tahun 2019

Pada gambar 4.a dan 4.b dapat terlihat bahwa hasil produktivitas varietas unggulan di Kecamatan Simpenan mengalami pergerakan yang fluktuatif. Produktivitas tertinggi untuk tanaman padi sawah terjadi pada bulan Maret yang mencapai 296 ton/ha. Hal ini di dukung oleh kondisi kekeringan di Kecamatan Simpenan pada bulan Maret berada pada kategori agak basah dengan nilai SPI $1.00 \mathrm{s.d}$ 1.23 (Gambar 1.b). Sedangkan produktivitas terendah untuk tanaman padi sawah terjadi pada bulan Agustus sebesar 54 ton/ha yang sesuai dengan kondisi kekeringan pada bulan Agustus berada pada kategori agak kering hingga kering dengan nilai SPI berkisar antara -1.19 s.d 1.99 (Gambar 2.b). Untuk produktivitas bawang merah, hasil produksi tertinggi terjadi pada bulan Februari yang mencapai $70 \mathrm{kwintal} / \mathrm{ha}$. Hasil produksi tersebut sesuai dengan kondisi pada bulan Februari yang berada pada kategori agak basah hingga basah dengan nilai SPI 1.00 s.d 1.71 (Gambar 1.a). Produktivitas bawang merah terendah terjadi pada bulan Agustus sebesar $43 \mathrm{kwintal} / \mathrm{ha}$, yang sesuai dengan kondisi kekeringan pada bulan Agustus berada pada kategori agak kering hingga kering dengan nilai SPI berkisar antara -1.19 s.d 1.99 (Gambar 2.b)

Kondisi kekeringan yang terjadi pada bulan Mei hingga Oktober memang mengalami penurunan produktivitas pertanian, namun masih dalam taraf aman dan tidak mengalami gagal panen (puso). Berdasarkan hasil observasi dan wawancara dengan petani di Kecamatan Simpenan selama periode musim kemarau yang mulai terjadi pada bulan Mei hingga Oktober, masih terjadi hujan dengan intensitas yang rendah namun frekuensinya teradinya rendah, kecuali pada bulan Agustus, selama 1 bulan tersebut tidak terjadi hujan. Untuk mengatasi kekeringan, para petani beserta warga di Kecamatan Simpenan membuat tampungan air mandiri seperti yang terjadi di Desa Loji. Para petani menampung air di musim hujan (bank air) kemudian 
dialirkan ke sawah pada saat periode musim kemarau menggunakan pompa (Gambar 5). Ada juga yang membuat membangun sumur dangkal (sumur bor) di lahan-lahan yang mengalami kekeringan. Kedalaman sumur bor tersebut mencapai 60 meter. Tindakan tersebut diharapkan dapat membantu dalam mengatasi kekeringan dan mengantisipasi terjadinya gagal panen.

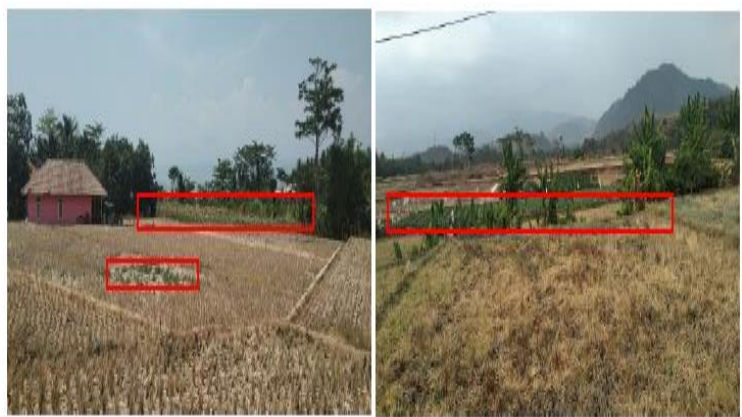

Gambar 5. Kondisi sawah di Desa Loji, Oktober 2019

\section{PENUTUP}

\section{Kesimpulan}

Besaran nilai SPI di Kecamatan Simpenan menunjukkan hasil yang berbeda-beda pada masing-masing periode defisit 1 bulan. Nilai SPI tertinggi terjadi pada bulan Januari hingga Februari dengan rentang nilai 1,00 s.d 1,71, yang termasuk dalam kategori agak basah hingga basah. Nilai SPI terendah terjadi pada bulan September hingga Oktober dengan rentang nilai -1,50 s.d-1,99.

Kekeringan yang terjadi di Kecamatan Simpenan berpengaruh terhadap hasil produktivitas pertanian unggulan yaitu bawang merah dan padi sawah. Meskipun para petani dan juga warga sekitar membuat penampung air dan juga sumur secara mandiri untuk mengatasi kekeringan, namun hasil yang dicapai belum maksimal. Air tanah dari sumur dan penampung air tersebut belum terdistribusi secara merata untuk mengaliri sawah. Kondisi tersebut dapat terlihat dari masih terjadi penurunan hasil produktivitas pertanian, sehingga pasokan air tanah yang mencukupi pada saat musim hujan masih sangat di andalkan untuk memenuhi kebutuhan air pada tanaman.
Bordi, I., Fraedrich, K. dan Sutera, A. (2009), "Observed Drought and Wetness Trends in Europe: An Update", Hydrology and Earth System Sciences, Vol.13, No.8, hal. 1519-1530. http://doi.org/https://doi.org/10.5194/hess-131519-2009.

BPBD Kabupaten Sukabumi (2019), Badan Penanggulangan Bencana Daerah. Diambil dari https://bpbd.sukabumikab.go.id/.

Jeyaseelan, A. (2004), "Droughts \& Floods Assessment and Monitoring using Remote sensing and GIS", dalam Satellite Remote Sensing and GIS Applications in Agricultural Meteorology,

Khan, M.A. (Inst of M. and G. dan Gadiwala, M.S. (Inst of M. and G. (2013), "A study of drought over Sindh (Pakistan) using standardized precipitation index (SPI) 1951 to 2010", Pakistan Journal of Meteorology (Pakistan), Diambil dari https://agris.fao.org/agrissearch/search.do?recordID=PK2014000138.

Kumar, M.N., Murthy, C.S., Sai, M.V.R.S. dan Roy, P.S. (2009), "On the Use of Standardized Precipitation Index (SPI) for Drought Intensity Assessment", Meteorological Applications, Vol.16, No.3, hal. 381-389. http://doi.org/10.1002/met.136.

McKee, T.B., Doesken, N.J. dan Kleist, J. (1993), THE RELATIONSHIP OF DROUGHT FREQUENCY AND DURATION TO TIME SCALES, http://doi.org/null.

Rahayu, S. P. (2011), Penyebab Kekeringan dan Upaya Penanggulangannya. Modul TOT Penyuluh Pertanian dalam Rangka Peningkatan Kesadaran Petani Terhadap Isu-isu Perubahan iklim serta Mitigasi dan Adaptasinya, Kerjasama Badan Litbang Pertanian dengan BMKG. Badan Penyuluhan dan Pengembangan Sumber Daya Manusia Pertanian. Kementan RI.,

Triatmoko, D., Susandi, A., Mustofa, M.A. dan Makmur, E.E.S. (2012), Penggunaan Metode Standardized Precipitation Index Untuk Identifikasi Kekeringan Meteorologi di Wilayah Pantura Jawa Barat. Diambil dari https://docplayer.info/38591131-Fakultas-ilmudan-teknologi-kebumian.html.

World Meteorological Organization (2017), Standardized Precipitation Index User Guide. Diambil 10 Mei 2020,

dari https://public.wmo.int/en/resources/library/st andardized-precipitation-index-user-guide. 